\title{
THE EFFECT OF GALLERY WALK STRATEGY ON STUDENTS' SPEAKING SKILL
}

\author{
$1^{\text {st }}$ Edy Waloyo \\ English Language Teaching Department \\ IAIN Syekh Nurjati Cirebon \\ edybueza@gmail.com
}

\author{
$2^{\text {nd }}$ Farchati \\ English Language Teaching Department \\ IAIN Syekh Nurjati Cirebon \\ farchatifarchati@gmail.com
}

Abstract: This research aimed to find out the effect of gallery walk strategy on students'
speaking skill at eleventh-grade students MA Darul Masholeh. The study took 24 students as
samples from two classes, that was XI IPA as an experimental class, and XI IPS as control
class. It used quantitative analysis which is designed as quasi-experimental. The technique of
collecting data is testing that is pre-test and post-test. The result showed that: 1). Students'
speaking skill without applying gallery walk strategy still under the standardized score of the
school, that is 64.00 . 2). Student's speaking skill by applied gallery walk strategy is
improved, and most of them succeed to pass the standardized score of the school, that is
84.00. 3). The effect of gallery walk strategy on students' speaking skill is a significant
influence. The gain between the pre-test and post-test score is 15.64 points. Because the t-test
result is t account (9.541)> t table at (df) 22 (2.07387)showed that the significance level (Sig.
(2-tailed)) was 0.00 which less than the significance level of 0.05 . ), so, Ho is rejected, and Ha
is accepted. It means that there is a significant effect of using gallery walk strategy on
students' speaking skill at MA Darul Masholeh in advertisement text at eleventh-grade
students of MA Darul Masholeh.
Keywords: Gallery Walk Strategy; quantitative research; Speaking skill.

\section{INTRODUCTION}

English is one of the essential languages in the education world. Most people in the world use English as the language of communication. English became one of the international languages. As a global language, English has a vital role to play in various aspects of human life. According to Brown (2007), the role of language is more than other abilities in processing information and behaving intelegently. English is a complex, specialized skill, which English is a complex, specialized skill, which spontaneously develops since child. It is clear that language is needed skill in every human because of it they can express their thought, concept and feeling by a meaningful symbol. Besides, language is used to extent information to others.

In addition, Snow (2006) states that the most fundamental reality of language learning is language as a tool for communication. Many students see English as anything. But in fact, English is potentially more appealing when English is present as a key for establishing communication with a new world. It means that seen from the side of anything, English is more appealing as a language used to communicate.

Speaking has primary function of language as a communication instrument. When students study a lot of speaking, they will have ability to be speakers. Speaking practice trains students to express their ideas. It has 
significant effect in communication especially to keep in touch directly. Therefore, it is a bridge to share information with other people.

Brown (2004) defines that English skill that can be observed directly and empirically is speaking. The ability of speaking is related the the accuracy and effectiveness of the listening skill. so the the reliability and validity of the infromation from listening skill will effect the oral production. It can be assumed that in learning speaking, pronunciation, intonation, grammar, and vocabulary are essential elements in communicative performance.

In other words, Florez (1999) argues that producing, receiving, and processing information is an interactive process of constructing meaning in speaking. It is clear that in conveying the valid meaning, people have to process the pattern, sound, and appropriate words to communicate with others. So, it can be concluded that in having good interaction in communication especially speaking English, people should understand the elements of speaking when they want to express ideas, opinions, or feelings to inform, persuade, and entertain.

Cameron (2001) argues that in order to make sense other people in social and educational context, English speaking has essential role to deliver meaning, and ideas in communication. Moreover, in producing appropriate utterances learners have to learn speaking linguistically and pragmatically (Martinez, 2006). In brief, students have to understand the use of language in many contexts.

According to Christine (2007), speaking plays significant role in communication because it not only give a chance to improve the language acquisition but also facilitate students to develop their speaking skill. When speaking English as the target language for instruction across the school curriculum, it is need as tool for thinking and learning. However, even in the process of speaking activities, it is probably alright to say that while speaking happens, the skills may not essential be taught.

Among four basic skills in English, speaking must be learned by students. It is needed for them to have communicatiom inside or outside the classroom. Students often considered that speaking is the most challenging skill to be learned. In this case, the students and teacher have to make warm engagement in the classroom to study English, create comfortable class atmosphere and equip the teachinglearning process with effective media. Richards (2008) says that priority for many second languages or foreign language learners is mastering English speaking skill. Consequently, learners often measure their success in language learning based on what they feel in their spoken language proficiency. It means students do comparison between what they have learned and felt.

Pollard (2008) argues that the most difficult aspects for students to master is speaking. It is surprisingly when students thinks the same things. It means that the students have to pay attention their ideas, language, vocabulary, how to use grammar, and pronunciation to have communication with others.

Extensive practice of speaking in a foreign language involves a variety of processes, and learning to perform all of them quickly. However, speaking skill was considered as a difficult skill to be acquired. It was captured in the students' skill to communicate in English. The students disposed to be silent in the classroom because they are 
not confidence. More practice are needed by students since students can train themselves to express their feeling, emotion, thought, and intention. Besides, the teacher was not aware the students' obstacles in speaking and did not create a comfortable situation in the process of teaching-learning in the classroom.

In speaking process, the students' difficulties covers lack of confidence, ashamedness, or even they thinks making mistakes serious problems in speaking. Sometimes, the students also difficult to deliver the detail information in some material. In fact, the students have ideas to deliver them but they face difficulty to speak what they what they want to share. Those obstacles are also faced by the students of XI class MA Darul Masholeh. Consequently, the process of teaching-learning speaking cannot be improved optimally because there are still some problems.

The students feel reluctant to express their ideas because of shy and difficult to deliver the detail information about the material to the other people, especially when they are given opportunity to share personal information or opinion. In addition, speaking in front of their classmates cause a bad worry and have impact to their speaking performance (Harmer, 2007). In such situations, the teacher has to help the students by giving more attention to them who need encouragement and support in speaking. When the students have more attention from the teacher, they will confident to learn English because they can ask some helps to the teacher if they face some problems

Based on the observation, there were some arguments that make the students have low speaking ability. It happens because of shy or lack of self- confidence in speaking English. Moreover, because English is not used in their daily life even though in simple expression, the process study of English has not been optimal. Sometimes the students' concentration are disturbed by some factors in the process of speaking in the classroom. Another problems often faced by students such as sleepy, misunderstand the material, shy to ask the teacher's help, and unfamiliar with dictionary. Consequently, they thought that learning English were not interesting, easy and essential for their daily life.

At school, monotonous teaching atmosphere makes some students feel lazy and get bored. The teacher as a very influential party in the teaching and learning process, the teacher's expertise and authority determines the continuity of the teaching and learning process in the classroom and its effects outside the classroom (Franscy and Fatimah, 2019). Selecting an appropriate technique in teaching English can trigger students to have a lot of practice in speaking. One of the techniques is the gallery walk strategy because it is interesting to be applied in teaching-learning process of speaking. Moreover, the gallery walk equips students' some clues or information that can be explored by the students

The gallery walk also allows the students to present individually or groups in displaying works, products and then they walk around the room looking at others works. This strategy has flexibility in the application. In this research, the researcher applied the Gallery Walk Strategy to teach speaking an advertisement.

On the other hand, Francek (2006) explains that the gallery walk is a technique of discussion which requires students to get out from the chair to join the communication. 
Flexibility is offered as the advantage of this strategy. It holds some benefits not only for the teacher but also for the students. Then, in the process, it has great power in opening, closing, or review activity. In this phase, students write on various pieces of chart paper or pictures that they have taped to the display walls.

The gallery walk gives the students chance to recall their prior knowledge and learn from one another. It serves bits of intelligence and many different ways for students who have different background knowledge to learn. This strategy also trains students' kinesthetic because it involves walking around and movements. Furthermore, it serves the interpersonal, and the verbal or linguistic learner because it covers small group interaction, discussion and written answers.

Asmani (2011), Gallery Walk strategy is referred to as the method of travelling groups. This strategy has a purpose for each group member to have a chance to participate and listen to the views and thoughts of other members. Other purposes of the Gallery Walk strategy are attracting students into topics to be studied, provide a chance for students to demonstrate their knowledge and beliefs about the topics to be discussed (correct or false understanding, invite students to find things deeper than the knowledge they have gained, allow students to develop their knowledge and skills (such as thinking, researching, communicating and cooperating) in gathering new information, provide an opportunity for students to sort, process and present newly acquired information and understanding, provide an opportunity for students to determine their own ways of demonstrating what has been learned (understanding, skills, attitudes and values) (Entrepreneurship Center).
The Strength of Gallery Walk strategy are Students accustomed to build a culture of cooperation to overcome problems in learning; there is a synergy of the mutual understanding of learning objectives, familiarize students to appreciate the results of learning his friend, activate the physical and students' mental during the learning process, familiarize students giving and receiving criticism. Then, the weakness of gallery walk strategy is if too many members will happen, some of the students hung the work of his friend, teachers must be extra careful in monitoring and assessing individual and collective activeness, more complicated class setting.

Francek (2006) argues that in promoting discussion in classroom Using Gallery walk, the students try to explore papers or pictures on the wall around the room. In sharing students' works with peers, teachers use this strategy as the alternative ways, because it requires them to attend physically, and move around the room. The common procedures of the gallery walk are:

The first is the students choose the text (e.g. quotations, documents, images, and/or students' work) for the gallery. The second is setting and placing text around the class. The setting of the documents should be displayed "gallery style" which allows students to have room tour around the classroom with some students classifying a particular text. It can be set on walls or arranged on tables. To reduce significant crowded, the texts are spread for enough space because it is the most important factor. Then, the students are instructed to follow how walk through the gallery. After that, the last instructions depend on the aim of the activity. The students are able to choose a gallery walk for themselves, 
partner or small groups, and when the group move to the next place in it must be announced.

Francek (2006) explains that the instructions based on the goals of teaching. The goal of teaching by using gallery walk is to enhance students' self-confidence in speaking. Therefore, the researcher modifies the instructions of teaching steps.

The first step, some materials needed such as several sheets or carton, glue, different colored pens and discussion questions are provided by the teacher. The second step, the class divided into group with four or five students' and the teacher share a different colored pen to each group. The third step, the teacher instruct the students to create and discuss gallery. The fourth step, each group is instructed to walk around the classroom to look at the next gallery. Each group has a duty to record the review of task, discussion, and questions and any answer. Then, adding information or comments with a colored pen that represents their own group are the duty of the members of the group. The fifth step is after a moment(about 3 minutes), the students' have to visit each gallery of the group. The sixth step is the students prepare the comments and brief oral report to present in the larger class about the gallery. This oral presentation as a chance for all the students to measure their understanding. The last step, at the end of learnin, the teacher adds comments and summarizes the discussion questions. Hence, the aim of this research is to find out the effect of the gallery walk strategy on students' speaking skill.

\section{METHOD}

This research is quantitative research. As stated by Mickey (2005), There are two types of quantitative research they are associational and experimental. Therefore, the researcher uses experimental design in carrying out the research. According to Fraenkle and Wallen (2008), definition experimental research as follows: one of the most powerful research methodologies is experimental research and it is the best way to establish cause-and-effect relationships among variables. It means that the data is difficult to be manipulated and must be aware of the factors that can influence the outcome and remove the research in such a way. It developed a logical association between manipulated factors and observed the effect.

This research was conducted at the eleventh-grade students of MA Darul Masholeh in academic year of 2019/2020. The researcher took two classes as the sample of this research. XI IPA consisted of 11 students as experimental class and XI IPS consisted of 13 students as control class. The instrument of this research was speaking skill test used in the pre-test and post-test. The speaking performance test is used to measure students' speaking skill. The results of the test were analyzed using SPSS v21.

There were 4 meetings in this research. The first meeting was a same pre-test for the two groups. The second and the third meeting, Experimental gave treatments by using gallery walk strategy to students' speaking skill but for the control group followed the textbook instruction. The last meeting was the same post-test for the two groups. The student's scores of pre-test and post-test were analyzed to know the student's speaking skill without applying gallery walk strategy and by applied gallery walk strategy. The data were analyzed by using t-test to compare the data two means score. 


\section{RESULT AND DISCUSSION}

To find out the speaking skill without applying gallery walk strategy on students speaking skill at eleventh grade of MA Darul Masholeh, the researcher gave test (pre-test) in student's control class. The test is used to know how far the achievement of speaking skill before giving a treatment. Here is the data score of pre-test and post-test in control class which was without applying gallery walk strategy.

Table 1

Table Distribution Frequency between Pre-test and Post-test in Control Class (XI IPS) Statistics

\begin{tabular}{lrrr}
\hline & & \multicolumn{1}{c}{$\begin{array}{c}\text { Pre-test } \\
\text { Control Class }\end{array}$} & \multicolumn{2}{c}{$\begin{array}{c}\text { Post-test } \\
\text { Control Class }\end{array}$} \\
\hline \multirow{2}{*}{$\mathrm{N}$} & Valid & 13 & 13 \\
\cline { 2 - 4 } & Missing & 0 & 0 \\
\hline Mean & 54.15 & 64.00 \\
\hline Mode & 52.00 & 60.00 \\
\hline Minimum & 48.00 & 60.00 \\
\hline Maximum & 60.00 & 80.00 \\
\hline Sum & 704.00 & 832.00 \\
\hline
\end{tabular}

Based on the statistics table above, the number of respondents is 13 students. Missing 0 indicates that the missing data is 0 . Therefore, there is no data that has not been processed.

Mean or pre-test average of 54.15, mode obtained 52, while the minimum and maximum score of each are 48 and 60 with the total number of pre-test 704. The Mean or post-test average of 64.00 , the mode is 60 , while the minimum and maximum score of each are 60 and 80 respectively with a total of 832 .

Table 2

Table Distribution Frequency between Pre-test and Post-test in Experimental Class (XI IPA) Statistics

\begin{tabular}{lrrr}
\hline & \multicolumn{1}{c}{$\begin{array}{c}\text { Pre-test } \\
\text { Experimental }\end{array}$} & $\begin{array}{c}\text { Post-test } \\
\text { Experimental }\end{array}$ \\
\hline \multirow{2}{*}{ V } & 11 & 11 \\
\cline { 2 - 4 } & Malid & 0 & 0 \\
\hline Mean & 68.36 & 84.00 \\
\hline Mode & 68.00 & $80.00^{\mathrm{a}}$ \\
\hline Minimum & 64.00 & 80.00 \\
\hline Maximum & 76.00 & 92.00 \\
\hline Sum & 752.00 & 924.00 \\
\hline
\end{tabular}


Based on table statistics above the number of respondents are 11 students. Missing 0 indicates that the missing data is 0 ; thus no data has not been processed.

The mean or average pre-test is 68.36. Mode obtained 68 while the minimum and the maximum score of 64 and 76 respectively with the total number of pre-test 752 . While Mean or average post-test of 84.00 , mode obtained 80 while the minimum and maximum score of each are 80 and 92 with a total of 924 .

\section{Chart 1 \\ To Compare Mean of Pre- and Post-test from Control and Experimental Class}

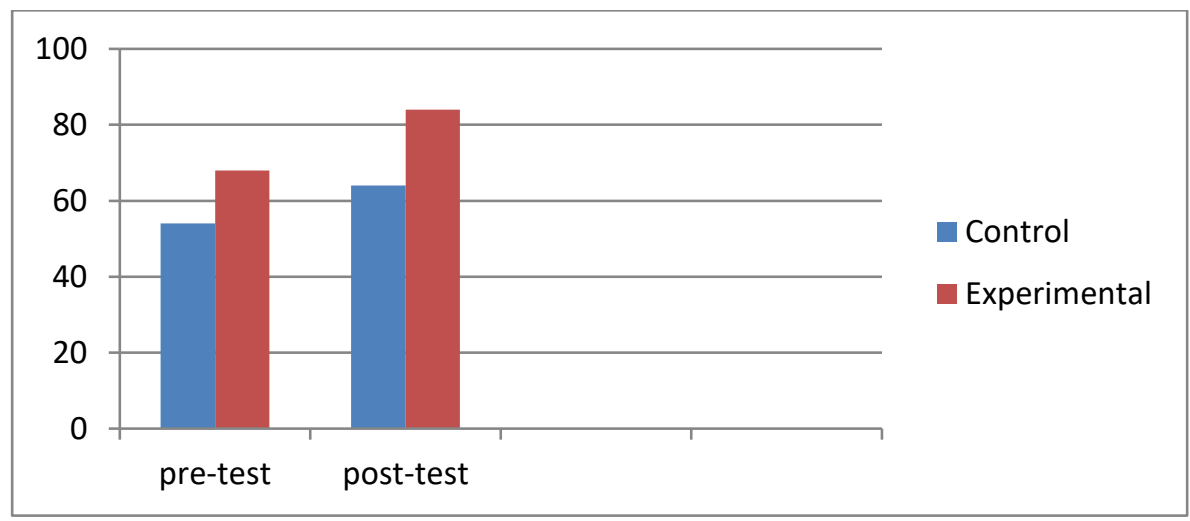

The chart above shows that the average of pre-test in control and experimental class a little bit different, in control class 54.15 whereas in experimental class 68.38 both of them gained only 14.23. Because of this, the researcher gives treatment for experimental class then the post-test result of both of class are 64.00 in the control class whereas in experimental class is 84.00 and the gain between them is 20.00. Thus post-test of experimental class higher than the average of the post-test score in the control class. Although both of class had an increase in speaking skill, the average of post-test in experimental class is higher than in control class. The pre-test and post-test average in control class are 54.15 and 64.00 with gain 9.85. Meanwhile, pre-test and post-test in experimental class are 68.38 and
84.00 with gain 15.62. It mean and indicated that gallery walk strategy has significant effect on students' speaking skill. It happened because of the advantages of the strategy in stimulating students to be active in the process of the teaching and learning process. Moreover, the students feel guided when they follow the instructions and clues which are presented on the gallery. It means that students are easy to express what are in their mind when they use gallery as their media in speaking.

After comparing the data of mean of pre-test and post-test, the researcher measure the normality of the test. It did determine whether the data were normally distributed or not. It was implemented in both experimental and control class. The researcher used 
Kolmogorov-Smirnov ${ }^{\text {a, }}$ especially as the statistic test. Level of significance of normality data is 0.05 . If the significant value is higher than 0.05 , the data is normal. Meanwhile, If the significant value is lower than 0.05 , the data is not normal. Here is the result of the normality test using SPSS v21.

Table 3

Table Normality Test One-Sample Kolmogorov-Smirnov Test

\begin{tabular}{|c|c|c|c|}
\hline & & $\begin{array}{c}\text { Post-test } \\
\text { Experimental } \\
\text { Class }\end{array}$ & $\begin{array}{c}\text { Post-test } \\
\text { Control Class }\end{array}$ \\
\hline \multicolumn{2}{|l|}{$\mathrm{N}$} & 11 & 13 \\
\hline \multirow[b]{2}{*}{ Normal Parameters, ${ }^{b}$} & Mean & 84.00 & 64.00 \\
\hline & $\begin{array}{l}\text { Std. } \\
\text { Deviation }\end{array}$ & 4.00000 & 5.88784 \\
\hline \multirow{3}{*}{$\begin{array}{l}\text { Most Extreme } \\
\text { Differences }\end{array}$} & Absolute & .227 & .290 \\
\hline & Positive & .227 & .290 \\
\hline & Negative & -.159 & -.248 \\
\hline \multicolumn{2}{|c|}{ Kolmogorov-Smirnov Z } & .754 & 1.046 \\
\hline \multicolumn{2}{|c|}{ Asymp. Sig. (2-tailed) } & .621 & .224 \\
\hline
\end{tabular}

a. Test distribution is Normal.

b. Calculated from data.

The results of normality test in Kolmogorov-Smirnov One-Sample table Test above, control class data showed significant score on Kolmogorov test of 0.621 . The significant score is above 0.05 . Then the control data is normally distributed.
Test the normality of the experimental class data showed significant score on the Kolmogorov test of 0.224 . The significant score is above 0.05 , so the experimental class data is normally distributed.

Table 4.

Table Independent Samples Test

Independent Samples Test

Levene's Test

t-test for Equality of Means

for Equality of

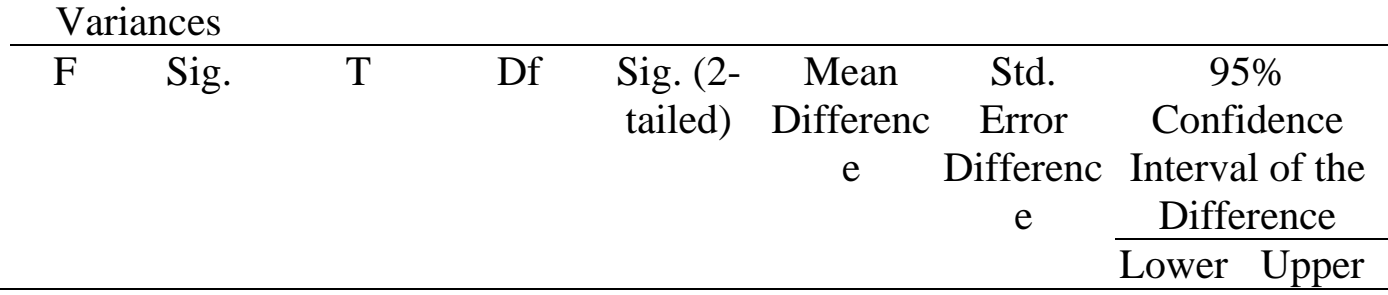




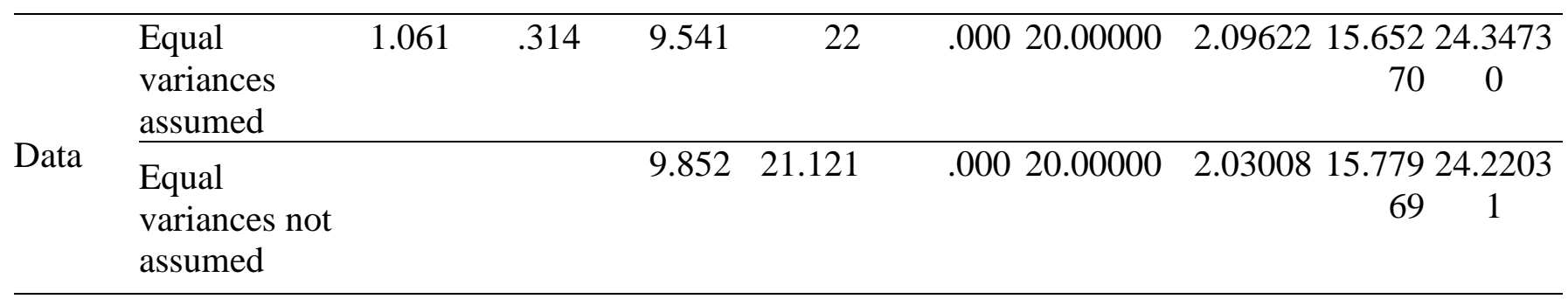

Basic decision making, namely:

If the value is sig. $>0.05$ and $\mathrm{t}$ arithmetic $<\mathrm{t}$ table, then $\mathrm{H} 0$ is accepted

If the value is sig. $<0.05$ and $t$ arithmetic $>\mathrm{t}$ table, then $\mathrm{H} 0$ is rejected

If $\mathrm{t}$ table is searched with $\alpha=0,05$ and $\mathrm{df}=22$, so $\mathrm{t}$-table $=2.07387$

Based on the test results independent sample test above a significant score of 0.000 . The significant score is smaller than 0.05 and $t$ arithmetic (9.541) is bigger than $t$ table (2.07387) then Ho is rejected, meaning there is difference of Experimental Class and control class score.

Related to the result of the study, the following explanation and discussions are served to strengthen the value of the research. First, the result showed that statistically there is significant effect in speaking skill comprehension between treatment class which used gallery walk strategy and textbook instruction in control class. It can be seen clearly from the mean score post-test of experimental class (84.00) was higher than the mean score post-test of control class ( 64.00). It can be concluded that gallery walk strategy did significant role in increasing students' speaking comprehension.

In the teaching process, the researcher stimulated the students' prior knowledge about the advertisement that they have watched or listened. It is conducted by asking some simple questions related to the picture about advertisement. For instance, the researcher showed and advertised the product of food and ask the students about their knowledge of it. It helps the them to understand the material because they have prior knowledge about it. Moreover, the activities of gallery walk strategy assists the students interested to the activities in the learning process.

Second, the successful learning and students mastery are claimed as result of the alternative hypothesis that shows the gallery walk strategy is effective for teaching speaking skill. It can strengthen the previous theory which proposed by Silberman (1996), the gallery walk is a method of presentation which allows group or individual show their work products (often on posters) and then have room our to look at each other works. The created works are welcome to be criticized by the learners in term of providing feedback to the group of individual. The statement above means that the students have to be active in applying gallery walk because it asks them walk throughout the classroom. They have to share ideas and respond to meaningful questions, images, and problem-solving situations or texts work together in small groups to. So, teach speaking and improves the student in speaking through gallery walk strategy can be effective and efficient.

Third, the null hypothesis proved learning speaking skill which used 
gallery walk strategy is effective. So, the goal of the research was achieved. It can be concluded that the gallery walk strategy is effective in teaching speaking, because there are some benefits for students that makes the process of teaching-learning is more active and interested. It means that students get easy to understand vocabulary which they use or receive in the process of speaking. Then, gallery walk strategy comes to help the students to increase their knowledge, easy to learn English, especially speaking.

\section{CONCLUSION}

Based on the result of data analysis, some conclusions are drawn as follow: the student ability in speaking skill in control class is generally low. It can be seen from the score obtained by the students in control class without being taught gallery walk strategy. The score pre-test from 13 students in control class is 704, and mean 54.15. While, the score post-test in control class is 832 , and mean is 64.00 . It can be concluded that there are some students not pass the pre-test and posttest.

\section{REFERENCES}

Asmani, Jamal Ma'mur,.(2011). 7 Tips Aplikasi PAKEM (Pembelajaran Aktif, Kreatif, Efektif, dan Menyenangkan).Jogjakarta: Diva Press.

Brown, H. Douglas. (2004). Language Assessment. New York: Longman.

Brown, H. Douglas. 2007. Principles of Language Learning And Teaching fifth Edition. Unite State of America: Longman.

Cameron, Deborah. (2001). Working with Spoken Discourse. Oxford: SAGE
The student ability in speaking before and after the implementation of gallery walk strategy in experimental class is showing the difference score. After the implementation of gallery walk strategy, students score in speaking is better than before. The score pre-test from 11 students in experimental class is 752 , and mean is 68.38. While, the score post-test in experimental class is 924 , and mean is 84.00.

There are significant effects of the use of gallery walk strategy on students speaking comprehension. The total score after being taught by gallery walk strategy is higher than before. It is showed by the result on the test results independent sample test, a significant score of 0.000 . The significant score is smaller than 0.05 and $t$ arithmetic (9.541) is bigger than $t$ table (2.07387) then Ho is rejected, it means that there is difference of control class and experimental class score. In conclusion, gallery walk strategy is effective used in teaching speaking for the eleventh grade students at MA Darul Masholeh

Florez, Mary A.C. (1999). Improving Adult English Language Learner's Speaking Skills. National Center for ESL Literacy Education on Center for Applied Linguistics of US Department of Education.

Fraenkel, Jack. R. and Norman E. Wallen. (2009). How to Design and Evaluate Research in Education Sixth Edition. Mc. Graw-Hill.

Francek, Mark. (2006). Promoting

Discussion in the Science Classroom Using Gallery Walks. Journal of College Science Teaching. http://www.nsta.org/publications/ 
[accessed 25 March 2019].

Franscy and Fatimah, Rezki P.S.N. (2019). An Analysis of Factors Influencing Learners' in Learning Language. DLEJ (Dialectical Literature and Education Journal). 4(1). 1-9. Retrieved from https://dlejpancasakti.ac.id/index.ph $\mathrm{p} / \mathrm{dlejpancasakti/issue/view/1}$

Goh, Christine C. M. (2007). Teaching Speaking in the Language Classroom. Singapore: SEAMEO Regional Language Centre.

Harmer, Jeremy. (2007). The Practice of English Language Teaching (4th ed). Harlow, U.K.: Longman.

Martinez, Flor Alicia. (2006). Current Trends in the Development and Teaching of the Four Language Skills (Studies on Language
Acquisition). Walter de Gruyter Gmbtl. \& Co. KG.

Mickey, Alison. (2005). Second Language Research Methodology and Design. London. Lawrence Eribaum Assosiates, Inc.

Pollard, L. (2008). Lucy Pollard's Guide to Teaching English: A book to Help You through Your First Two Years in Teaching.

Richards, Jack C. (2008). Teaching Listening and Speaking: From Theory to Practice: Cambridge: Cambridge University Press.

Silberman, Mel. (1996). Active learning: 101 Strategies to Teach Any Subject. U.K. A: Pearson Education Company.

Snow, Don. (2006). More Than Native Speaker. USA: TESOL. 